\title{
CONTENTS OF VOLUME 54
}

(Page numbers are at the end of each entry)

\section{ARTICLES AND COMMUNICATIONS}

Bishop, Jennifer Utopia and civic politics in mid-sixteenth-century London

Burns, Arthur and Stray, Christopher The Greek-play bishop: polemic, prosopography, and nineteenth-century prelates . . . . . . 1013

Campbell, James African Americans and parole in depression-era New York 1065

Clark, Matthew The gentry, the commons, and the politics of common right in Enfield, c. $155^{8-c .1603}$. . . . . . . .

Dialeti, Androniki Defending women, negotiating masculinity in early modern Italy

Dubow, Saul Macmillan, Verwoerd, and the 1960 'wind of change' speech

Early Modern Research Group Commonwealth: the social, cultural, and conceptual contexts of an early modern keyword

Edwards, Andrew; Tanner, Duncan; and Carlin, Patrick The Conservative governments and the development of Welsh language policy in the 1980 s and 1990 . . . . . . . . . . . .

Farrant, Andrew and McPhail, Edward A substitute end for socialism?

F. A. Hayek and Keynesian full-employment policy

Glickman, Gabriel Gothic history and Catholic Enlightenment in the works of Charles Dodd (1672-1743)

Greenspan, Nicole Charles II, exile, and the problem of allegiance

Harris, Bob Cultural change in provincial Scottish towns, c. $1700-1820$

Jackson, Alvin 'Tame Tory hacks'? The Ulster party at Westminster, 1922-1972

Jones, Matthew Great Britain, the United States, and consultation over use of the atomic bomb, 1950-1954 . . . . . . . . .

Levitin, Dmitri Matthew Tindal's Rights of the Christian Church (1706) and the church-state relationship

MacCulloch, Diarmaid Foxes, firebrands, and forgery: Robert Ware's pollution of Reformation history

Macdonald, Alan R. Consultation and consent under James VI . .

Merritt, J.F. Contested legitimacy and the ambiguous rise of vestries in early modern London

Midgley, Clare Transoceanic commemoration and connections between Bengali Brahmos and British and American Unitarians . . .

Mold, Alex Making the patient-consumer in Margaret Thatcher's Britain

Moss, Eloise Burglary insurance and the culture of fear in Britain, c. 1889-1939

Ortolano, Guy Planning the urban future in 1960 B Britain

Page, Anthony Rational dissent, Enlightenment, and abolition of the British 
Qureshi, Sadiah Robert Gordon Latham, displayed peoples, and the natural history of race, $1854^{-1} 866$

Roberts, T. W. Republicanism, railway imperialism, and the French empire in Africa, 1879-1889

Roper, Michael Nostalgia as an emotional experience in the Great War

Rose, Jacqueline Kingship and counsel in early modern England

Sapire, Hilary African loyalism and its discontents: the royal tour of South Africa, 1947

Schui, Florian Taxpayer opposition and fiscal reform in Prussia, c. $1766-1787$

Sowerby, Tracey A. Richard Pate, the royal supremacy, and Reformation diplomacy

Stack, David The death of John Stuart Mill

Stein, Tristan Tangier in the Restoration empire . . . . . . .

Thackeray, David Rethinking the Edwardian crisis of Conservatism

Winship, Michael P. Defining puritanism in Restoration England: Richard Baxter and others respond to A friendly debate.

Withington, Phil Intoxicants and society in early modern England

\section{REVIEW ARTICLES AND HISTORIOGRAPHICAL REVIEWS}

Klautke, Egbert Anti-Americanism in twentieth-century Europe

Mailer, Gideon Nehemias (Scotus) Americanus: Enlightenment and religion between Scotland and America . . . . .

Marshall, Peter Disenchantment and re-enchantment in Europe, $125^{\circ}-1920$

Middleton, Roger Brittan on Britain: 'The economic contradictions of democracy' redux

Milne, David How front organisations played the CIA . . . .

Morgan, Simon Between public and private: gender, domesticity, and authority in the long nineteenth century .

Moses, A. Dirk Paranoia and partisanship: genocide studies, holocaust historiography, and the 'apocalyptic conjuncture'

Petley, Christer New perspectives on slavery and emancipation in the British Caribbean

Raponi, Danilo Heroism, vice, and the Risorgimento

Smith, David L. The varieties of politics in early modern Britain and Ireland

Smith, S. D. Determining the industrial revolution

Alexander, Julia Marciari and MacLeod, Catherine (eds.) Politics, transgression, and representation at the court of Charles II. By Grant Tapsell

Allen, Robert C. The British industrial revolution in global perspective. 
Aylmer, G. E. The crown's servants: government and civil service under Charles II I 660-I 685. By Grant Tapsell

881

Banks, Stephen A polite exchange of bullets: the duel and the English gentleman, I 750-I 850. By Mark Towsey

Bayly, C. A. and Biagini, Eugenio F. (eds.) Giuseppe Mazzini and the globalization of democratic nationalism, I830-1920. By Danilo Raponi

Beaver, Daniel C. Hunting and the politics of violence before the English Civil War. By David L. Smith

Bush, Julia Women against the vote: female anti-suffrage in Britain.

By Simon Morgan

Cameron, Euan Enchanted Europe: superstition, reason, and religion, I 250-I75O. By Peter Marshall

Cook, Simon The intellectual foundations of Alfred Marshall's economic science: a rounded globe of knowledge. By Jocelyn Paul Betts

1185

Delap, Lucy; Griffin, Ben; and Wills, Abigail (eds.) The politics of domestic authority in Britain since I 800 . By Simon Morgan

Dunan-Page, Anne and Lynch, Beth (eds.) Roger L'Estrange and the making of Restoration culture. By Grant Tapsell

Fisher, Michael H. The inordinately strange life of Dyce Sombre, Victorian Anglo-Indian MP and Chancery 'lunatic'. By Mark Towsey

Gleadle, Kathryn Borderline citizens: women, gender and political culture in Britain, I815-I867. By Simon Morgan

Goldie, Mark (ed.) Roger Morrice and the puritan Whigs: the entring book of Roger Morrice, I677-I69I. By David L. Smith

1169

Gruber, Ira D. Books and the British army in the age of the American Revolution. By Mark Towsey

Humphries, Jane Childhood and child labour in the British industrial revolution. By S. D. Smith

Hunt, Alice The drama of coronation: medieval ceremony in early modern England. By David L. Smith

Hutton, Ronald Debates in Stuart history. By Grant Tapsell $\cdot \dot{ } \cdot$
Isabella, Maurizio Risorgimento in exile: Italian émigrés and the Liberal International in the post-Napoleonic era. By Danilo Raponi . .

Kane, Brendan The politics and culture of honour in Britain and Ireland, I54I-I64I. By David L. Smith . . . . . . .

Little, Patrick and Smith, David L. Parliaments and politics during the Cromwellian Protectorate. By Grant Tapsell . . . . . .

McCormack, Matthew (ed.) Public men: masculinity and politics in modern Britain. By Simon Morgan

McCorristine, Shane Spectres of the self: thinking about ghosts and ghost-seeing in England, I750-I920. By Peter Marshall

McElligott, Jason Royalism, print and censorship in Revolutionary England. By Grant Tapsell

McElligott, Jason and Smith, David L. (eds.) Royalists and royalism during the English Civil Wars. By Grant Tapsell . . . . . . . . .

McElligott, Jason and Smith, David L. (eds.) Royalists and royalism during the Interregnum. By Grant Tapsell 
Mackie, Erin Rakes, highwaymen, and pirates: the making of the modern gentleman in the eighteenth century. By Mark Towsey

Matikkala, Antti The orders of knighthood and the formation of the

British honours system, I660-I760. By David L. Smith

Midgley, Clare Feminism and empire: women activists in imperial Britain, I 790-I 865. By Simon Morgan

Milton, Anthony Laudian and royalist polemic in seventeenth-century England: the career and writings of Peter Heylyn. By Grant Tapsell

Nechtman, Tillman W. Nabobs: empire and identity in eighteenth-century Britain. By Mark Towsey

Patriarca, Silvana Italian vices: nation and character from the Risorgimento to the Republic. By Danilo Raponi . . . . . . . .

Pearsall, Sarah M. S. Atlantic families: lives and letters in the later eighteenth century. By Mark Towsey

Raymond, Joad Milton's angels: the early-modern imagination. By Peter Marshall

Riall, Lucy Garibaldi: invention of a hero. By Danilo Raponi . . .

Rublack, Ulinka Dressing up: cultural identity in Renaissance Europe. By Beverly Lemire

Saunders, Frances Stonor Who paid the piper? The CIA and the cultural Cold War. By David Milne.

Scirocco, Alfonso (trans. Allan Cameron) Garibaldi: citizen of the world. By Danilo Raponi . . . . . . . . . .

Steedman, Carolyn Labours lost: domestic service and the making of modern England. By Simon Morgan

Twells, Alison The civilising mission and the English middle class, I792-I850. By Simon Morgan

Von Eschen, Penny Satchmo blows up the world: jazz ambassadors play the Cold War. By David Milne

Weiner, Tim Legacy of ashes: the history of the CIA. By David Milne .

Wilford, Hugh The mighty Wurlitzer: how the CIA played America.

By David Milne .

Wrigley, E. A. Energy and the English industrial revolution. By S. D. Smith 


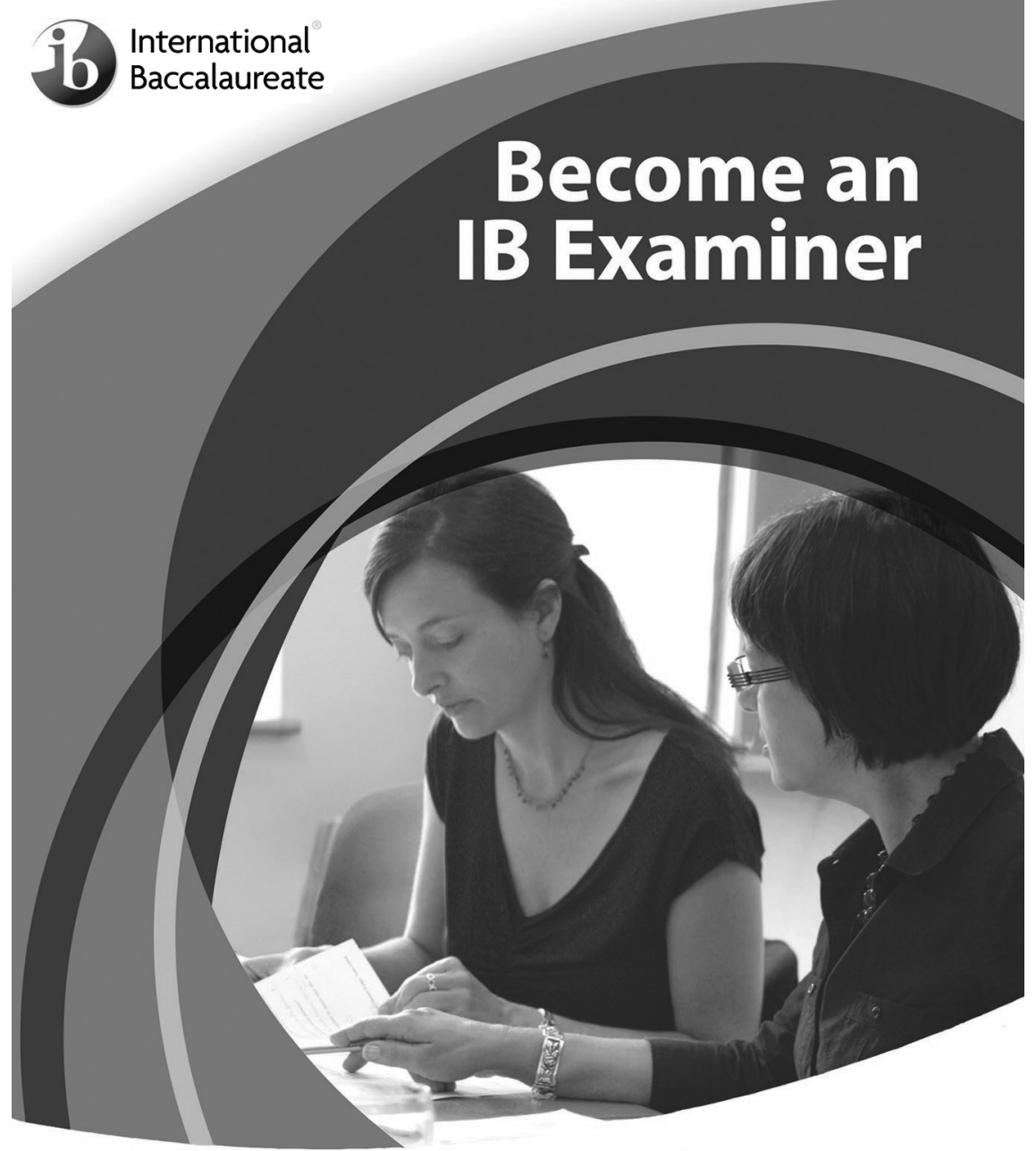

\section{History Examiner positions now available}

IB history provides both structure and flexibility, fostering an understanding of major historical events in a global context. It invites comparisons between, but not judgments of, different cultures, political systems and national traditions.

IB Examiners assess the work of students from 138 countries. They play an important role in maintaining the quality of assessment for which the International Baccalaureate is known worldwide.

For more information and to apply, please visit our website: www.ibo.org/examiners 


\section{European Review of Economic History}

Published for the European Historical Economics Society

\section{Editors}

Cormac Ó Gráda, University College Dublin, Ireland Jaime Reis, Universidade de Lisboa, Portugal

Hans-Joachim Voth, Universitat Pompeu Fabra, Spain

\section{EREH - 2nd Highest Ranked Economic History Journal in latest JCR Reports}

European Review of Economic History has established itself as a major outlet for high-quality research in economic history, which is accessible to readers from a variety of different backgrounds. The Review publishes articles on a wide range of topics in European, comparative and world economic history. Contributions shed new light on existing debates, raise new or previously neglected topics and provide fresh perspectives from comparative research. The Review includes fulllength articles, shorter articles, notes and comments, debates, survey articles, and review articles. It also publishes notes and announcements from the European Historical Economics Society.

\author{
To subscribe contact \\ Customer Services \\ in Cambridge: \\ Phone +44 (0)1223 326070 \\ Fax +44(0)1223 325150 \\ Email journals@cambridge.org \\ in New York: \\ Phone (845) 3537500 \\ Fax (845) 3534141 \\ Email \\ subscriptions_newyork@cambridge.org
}

Free email alerts

Keep up-to-date with new material - sign up at

journals.cambridge.org/register

For free online content visit: http://journals.cambridge.org/ere 
This journal is registered with the Copyright Clearance Center, 222 Rosewood Drive, Danvers, MA oI923, USA. Organizations in the USA who are also registered with the C.C.C. may therefore copy material (beyond the limits permitted by sections IO7 and Io8 of US Copyright law) subject to payment to C.C.C. of the per copy fee of \$12.0o. This consent does not extend to multiple copying for promotional or commercial purposes. Code oor8-246x/ i \$12.0o. ISI Tear Sheet Service, 350 M Market Street, Philadelphia, PA I9I04, USA, is authorized to supply single copies of separate articles for private use only. Organizations authorized by the Copyright Licensing Agency may also copy material subject to the usual conditions. For all other use, permission should be sought from Cambridge University Press.

\section{INSTRUGTIONS FOR GONTRIBUTORS}

I The Historical fournal publishes articles on all aspects of history since the fifteenth century.

2 All contributions, correspondence, and books for review should be sent to: The Editors, The Historical Fournal, Faculty of History, West Road, Cambridge CB3 9EF. The e-mail address is hj@hist.cam.ac.uk. Fax: +(0) 1223 335968. Please mark faxes "for editors of Historical Journal". Tel No: +44(0) 1223335347.

3 Articles should not exceed 10,000 words and Communications 5,000 words in length. Historiographical reviewes should not exceed 8,000 words. Contributions must follow the layout and stylistic conventions of The Historical Fournal. Detailed Instructions for Contributors should be consulted at http://journals.cambridge.org/his

4 Three paper copies of all submissions (articles, communications, review articles, historiographical reviews, single reviews) should initially be submitted. Two of the copies should be anonymous. Receipt of submissions will be acknowledged by email; and authors will then usually be asked to submit an electronic copy as an email attachment.

5 Submission of material will be taken to attest that it is unpublished (even in a language other than English) and is not at present being considered for publication elsewhere. Upon acceptance of a paper, the author will be asked to assign copyright (on certain conditions) to Cambridge University Press.

6 The Journal is willing to consider unpublished articles submitted in languages other than English, and in such cases a short resumé (max. one page) in English should accompany the submission. Financial assistance may be offered by the Journal towards the costs of translation into English.

7 Figures must be submitted electronically, scanned at a minimum of 320 dpi and saved as either TIFF or EPS files; if you wish to compress them, use lossless compression software such as the LZW compression package. Illustrative material should be numbered as part of a sequence of figures. Figure captions are to be supplied on a separate sheet.

8 Contributors are responsible for obtaining permissions to reproduce all material for which they do not hold copyright for worldwide publication in all forms and media, including electronic publication, and for ensuring that the appropriate acknowledgements are included.

9 The Editors endeavour to provide a decision on contributions within three months, and thereafter to publish those accepted within eighteen months. They reserve the right to change publication date at short notice, owing to space constraints and the need to achieve balance of content.

This journal issue has been printed on FSC-certified paper and cover board. FSC is an independent, non-governmental, not-for-profit organization established to promote the responsible management of the world's forests. Please see www.fsc.org for information.

(C) Cambridge University Press 20I I

\section{CAMBRIDGE UNIVERSITY PRESS}

The Edinburgh Building, Cambridge $\mathrm{CB}_{2}$ 8RU, United Kingdom

32 Avenue of the Americas, New York, NY Ioor3-2473, USA

477 Williamstown Road, Port Melbourne, VIC 3207, Australia

Ruiz de Alarcón I3, 28014 Madrid, Spain

Dock House, The Waterfront, Cape Town 8oor, South Africa

Printed in the United Kingdom by the University Press, Cambridge 


\section{THE HISTORICAL JOURNAL}

\section{CONTENTS}

\section{ARTICLES}

JENNIFER BISHOP Utopia and civic politics in mid-sixteenth-century London

ARTHUR BURNS AND CHRISTOPHER STRAY The Greek-play bishop: polemic, prosopography, and nineteenth-century prelates

ELOise Moss Burglary insurance and the culture of fear in Britain, 1889-1939

\section{COMMUNICATION}

ANDREW FARRANT AND EDWARD MCPHAIL A substitute end for socialism?

F. A. Hayek and Keynsian full-employment policy

Historiographical Reviews

EGBERT KLAUTKE Anti-Americanism in twentieth-century Europe

\section{Review ARticles}

MARK TOWSEY An empire of print

DANILO RAPONI Heroism, vice, and the Risorgimento

SIMON MORGAN Between public and private: gender, domesticity, and authority in the long nineteenth century

OTHER REVIEW

BEVERLY LEMIRE Ulinka Rublack Dressing up: cultural identity in Renaissance Europe

\section{Cambridge Journals Online}

For further information about this journal please go to the journal website at: journals.cambridge.org/his

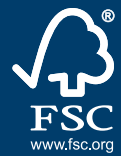

MIX
CAMBRIDGE UNIVERSITY PRESS 